\title{
A Review of Manufacturing in Australia
}

\author{
Maruf Hasan \& Asare Boateng \\ The University of New South Wales, Sydney 2052, Australia \\ E-mail:m.hasan@unsw.edu.au
}

Received: June 7, 2017 Accepted: June 27, 2017 Online published: July 10, 2017

doi:10.5296/jpag.v7i3.11522ＵRL: https://doi.org/10.5296/jpag.v7i3.11522

\begin{abstract}
Manufacturing as a share of Australia's gross domestic product has constantly declined since 1960. In 2016 manufacturing activity accounted for less than $10 \%$ of gross domestic product and employed less Australians than ever before. The paper intends to review the history of manufacturing in Australia and evaluate the condition of the sector in 2016. After this evaluation; recommendations are made on how both governments and businesses can reform to rejuvenate growth. An extensive analysis of the literature in conjunction with interviews with different Australian manufacturing businesses was used to execute the analysis. The literature emphasised tariff removal, a high Australian dollar and an increasingly globalised world as the primary causes of manufacturing's decline. Businesses highlighted the geographical isolation of the nation, the low population, high labour costs and the high Australian dollar as some of the barriers to growth of the sector. Focusing on new advanced manufacturing technologies, reducing corporate tax and improving public infrastructure are some of the recommendations made to help the sector reverse the negative trend. The evaluation of the sector with these recommendations is significant to both governments and businesses as it provides avenues for growth and investment relevant to the post mining boom economy.
\end{abstract}

Keywords: Manufacturing, Technology, Business, Economy

\section{Introduction}

Manufacturing has been a pivotal component of the Australian economy and community since federation in 1901. Australians have relied on the manufacturing sector to provide goods customised to its unique landscape. From cars to clothing the manufacturing knowledge has existed to create these items. From the economic highs in the 60's, the past 50 years has seen manufacturing suffer a constant percentage decline in its contribution to the national GDP. Industry representatives, governments and economists have constantly attempted to reverse this negative trend. Protectionist policies, extra R\&D funding, tax cuts and so forth have so far been unsuccessful and occasionally made the situation worse. 


\section{Mll Macrothink}

Journal of Public Administration and Governance

ISSN 2161-7104

2017, Vol. 7, No. 3

This paper is intended to outline the history of manufacturing in Australia and evaluate the condition of the sector at present. For the first time in over 10 years the sector has looked promising with a low Australian dollar and the realisation that the mining boom is over. This may be short lived as another spike in the Australian dollar may further reduce the global competitiveness of the sector. If conditions remain stable it may give Australian manufacturers a final opportunity to reform, reinvest and to once again be smart innovative players in all manufacturing subcategories. The research will provide avenues for businesses, governments and the community to follow to enable the sector to prosper.

Is advanced manufacturing technology the best investment for Australian manufacturing businesses? Should the government restrict or raise tariffs on certain imported goods? Are corporate taxes and regulation stifling investment? Should the government invest in innovation or should that be up to businesses? Can industry work better with universities and researchers? These questions will be answered to deliver a multifaceted solution to this complex problem. What is proposed may take years before conclusions can be drawn on its effectiveness. The proposals are aimed to instil a fundamental change in the sector rather than a band-aid fix.

Manufacturing in Australia is currently at a crossroad. Reform and reinvest or continue the slide to irrelevance. This research is important as the mistakes of the past can be analysed and evaluated in order to form accurate decisions for the future. Advanced manufacturing is currently proving advantageous for some western nations. This could be enough to reverse the negative trend for Australia. In order to form a list of comprehensive recommendations, research will be gathered from high value sources such as journal articles, economic statistics and government legislation. Interviews with individuals employed/involved in the manufacturing sector will be conducted in order to ascertain the condition of the sector and to reveal potential solutions that may be utilised to aid the sector.

In order to determine the history of manufacturing in Australia, the literature review has been organised in a chronological order. Following the literature review the methodology used throughout the research is explained. Results gained through research and interviews are succinctly outlined. A discussion is then conducted on these results which form the basis of the recommendations that can be used to transform the sector. Finally the thesis is concluded summarising and evaluating the condition of Australian manufacturing.

\section{Literature Review}

In 2003 the Productivity Commission released a significant report detailing the trends in Australian manufacturing over the past 40 years. The report described how "Manufacturing accounted for one in four dollars of national output in the 1960s but only one in eight by the turn of the century" [Productivity Commission, 2003]. The decline in manufacturing during this time was due to the strong uptake in services as household incomes rose. Offshoring of manufacturing and cheap importation was not a leading contributor to the decline.

In 2002 one million Australians were employed in manufacturing which accounted for \$273 billion dollars of national sales. Manufacturing in medical and pharmaceutical goods, 


\section{Macrothink}

Journal of Public Administration and Governance

ISSN 2161-7104

2017, Vol. 7, No. 3

photographic and scientific equipment saw a substantial increase in the past 40 years. This finding helps to show the move away from low cost, high volume production.

Exports had increased in manufacturing by over 15\% in the years from 1990 to 2000 [Productivity Commission, 2003]. Increased competitiveness of manufactured goods in Australia has correlated to the sector being one of the biggest contributors to R\&D (Research and Development). In 2002 this contribution was valued at two billion dollars. Figure 2 shows the steady decline in the manufacturing sector prevalent over the past 40 years.

In 2009, low cost, high volume manufacturing industries such as clothing started to shift their manufacturing overseas. Australian brand 'Bonds' moved 1850 manufacturing jobs to China even after a \$17.6 million dollar government grant was given [Hasan, et al., 2011]. Even with such strong incentives and a vast public outcry against the move it was not enough to change the corporate board's decision.

The current climate of manufacturing in Australia has seen a dramatic turn in the past decade since 2002. "Australia's 'Two Speed Economy" addresses how Australia's economic focus after the global financial crisis shifted to the mining sector. High commodity prices stimulated mining exports and overshadowed the vast slowdown in manufacturing, finance and tourism [Perlich, 2012]. Strong investment in mining production correlated with a sharp rise to the Australian dollar. "The Australian dollar went from a low in 2001 to a post-float record high in 2011, more than doubling in value in this period from US\$0.49 to a peak of US\$1.10” [Perlich, 2012]. This is clearly seen in Figure 1.

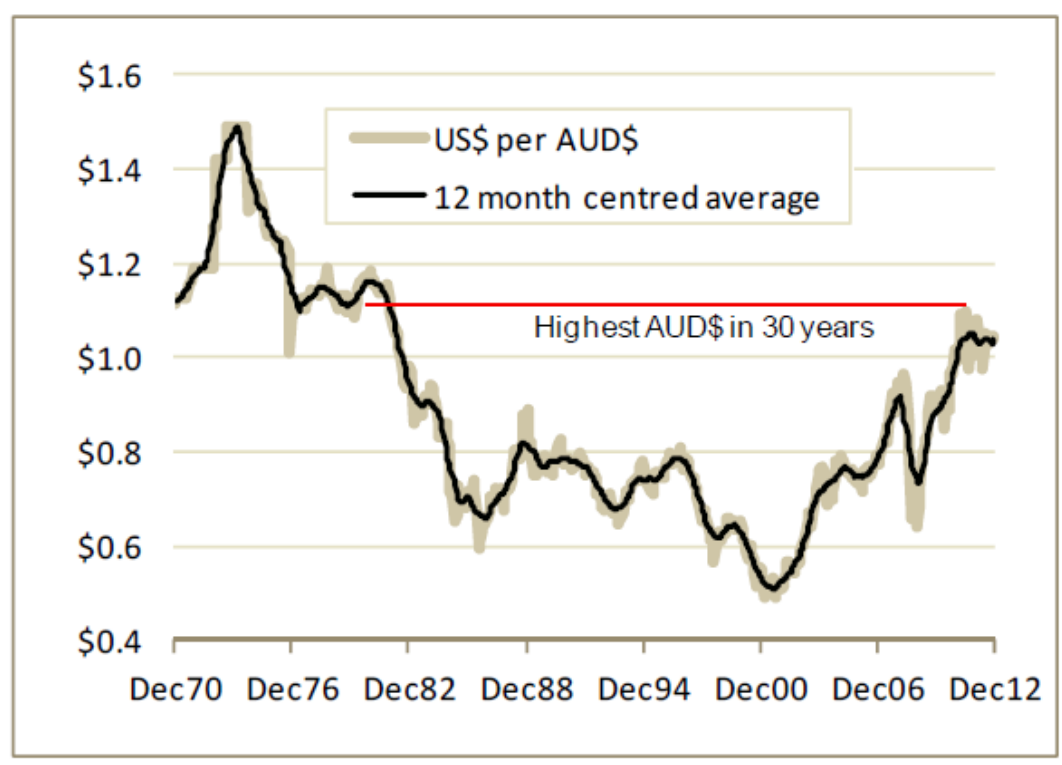

Figure 1. Value of the Australian currency against the US Dollar, 1970-2012 [Perlich, 2012]

The value of the Australian dollar is very important for Australian manufacturers to remain globally competitive. A high Australian dollar works against many sectors of the nation. Consequently, total manufacturing employment in NSW fell by 15\% in 10 years since 2002 . Car manufacturing has also been weak with vast Toyota layoffs in 2012 and Ford Motors 
announcing an end to car production in Australia [Perlich, 2012].

In 2012 the prime minister's manufacturing taskforce commission a report on the current state of manufacturing in Australia and the improvements that need to be made in order to stop its decline. The report acknowledge that over 100,000 jobs in manufacturing have been lost since the global financial crisis and the significant impact this was having on Australian communities [Prime Minister's Manufacturing Taskforce 2012]. Similarly the high Australian dollar was blamed as the largest contributor to this decline. Again just like the Productivity Commission in 2002, the taskforce shared "a deep optimism about the capacity of Australian manufacturing to compete effectively" and how Australia is embarking on the "Asian Century" [Prime Minister's Manufacturing Taskforce 2012].

The Productivity Commission released their 2015 productivity update which outlined the current state of the manufacturing sector in Australia. Manufacturing represented $7.5 \%$ of national GDP for 2013-14. The manufacturing sector saw output growth drop 1.8\% for that year and capital input drop 1.1\% [Productivity Commission 2014]. Manufacturing has continued to fall after the new policy directions introduced by the liberal government. The majority of the policy tools have been useless in stopping this decline for over a decade.

The Australian Industry (Ai) group is one of Australia's leading associations representing and reporting on industry and productivity. In October 2015 their Australian dollar annual report was released detailing the flotation of the dollar over the past 15 years. By the end of September 2015 the dollar had dropped 33\% in comparison to September 2013 against the USD [Ai Group, 2015]. This substantial drop was assumed by the Ai group to correlate with international commodity prices. Figure 4 depicts the strong relationship the AUD has with commodity prices.

\section{Methodology}

The thesis utilises two principal approaches to gather information and past judgement on the sector. First is research through literature and the second is gathering information through interviews.

\subsection{Research Methodology}

Gathering information from journal articles, economic statistics and government legislation will be the primary sources when passing judgement on the Australian manufacturing sector. Once all relevant information has been sourced the current landscape of the sector can be identified and analysed. Examining the inherent problems in the sector will be one of the principal focuses of the analysis.

In order to ascertain potential solutions to these problems, individuals and industry groups will be invited to discuss their personal ideas on tackling these problems. These solutions may range from a business's investment direction, managerial change, public perception change or possible government policy reform.

Detailed analysis on new advanced manufacturing practices will be introduced as another potential solution. The viability of these technologies and other solutions utilised in other 
countries will be evaluated and determined if applicable to Australia in its current state.

Throughout this whole thesis there will be no perception of one singular solution to the constant decline of the manufacturing sector over the past 50 years. Severally small changes over a large period of time is the only true way of creating beneficial change in the sector.

\subsection{Interview Methodology}

The aim of conducting interviews is to gather information from individuals employed/involved in the Australian manufacturing industry to determine if their opinions are consistent with academic literature. The academic literature is currently suggesting that a high Australian dollar is one of the most significant obstacles facing the manufacturing industry. Advanced manufacturing however has been noted by many economic scholars to have the potential to stimulate a resurgence in manufacturing in western nations.

Generalised questions about the Australian manufacturing sector would be put to 3-10 people either through face to face interviews, telephone or emails. The face to face interviews and telephone interviews should last approximately 30 minutes. This sample size should allow a thorough discussion that will enable comparison to the academia. All participants will either be employed in the Australian manufacturing industry or involved with it throughout their career. Most of the contact details have been obtained through publicly available means such as websites. Only two participants have been identified through private means. All participants will be initially recruited through an initiation letter sent via email.

If an interview is conducted voice recordings for all of the interview will be conducted. Written notes will also be utilised to highlight important answers during the interview. Relevant ethics approval was obtained to conduct the interview and related matters.

Detailed below were the questions asked during the interview process.

1) Where do you see the Australian manufacturing industry in five year's time?

2) Is advanced manufacturing key to the sector's growth?

3) What is your company doing with advanced manufacturing technology?

4) Are there any advanced manufacturing technologies that you are excited about, either within or outside of your company?

5) What are some of the problems embedded in the Australian manufacturing sector?

6) What can Australia do in comparison to the likes of Germany and Canada?

7) I have identified that a high Australian dollar is one of the biggest influences in the Australian manufacturing sector. Do you agree with this statement and could you elaborate on your answer.

8) How significant do you believe labour costs impact manufacturing in Australia?

9) Does the currently low interest rate and inflation figures have an impact on Australian manufacturing? 


\section{Results and Analysis}

The results obtained from the literature outlining the current state of manufacturing in Australia will be collated and analysed. All interview participants' answers have been summarised for brevity with the strongest intent to not misrepresent an answer. Five participants agreed to be interviewed. These five participants spanned from four different Australian manufacturing businesses.

\subsection{Results from Literature}

Several key results have been discovered through extensive research of the literature. The manufacturing sector has been in constant decline (in terms of percentage contribution to GDP) over the past 50 years [Davidson, 1969]. One of the biggest reasons for this decline started in the late 1960's when Australian made products were globally uncompetitive. This was caused by the federal government increasing tariffs on imports to try and protect the local manufacturing sector. This encouraged growth locally but with the removal of these tariffs and other protectionist policies in the 1980 the sector's decline increased. Protectionism allows businesses to ease investment, stop innovation and not diversify their operations. In hindsight these policies should have never been introduced.

\begin{tabular}{|c|c|c|c|c|c|c|}
\hline \multirow{2}{*}{$\begin{array}{l}\text { Trading range for } \\
\text { AUD/USD: }\end{array}$} & \multicolumn{3}{|c|}{ Competitive in export markets } & \multicolumn{3}{|c|}{ Competitive against imports } \\
\hline & 2015 & 2014 & 2011 & 2015 & 2014 & 2011 \\
\hline $0.50-0.60$ & 100 & 100 & 100 & 100 & 100 & 100 \\
\hline $0.61-0.70$ & 98 & 97 & 95 & 98 & 94 & 91 \\
\hline $0.71-0.80$ & 94 & 95 & 93 & 94 & 92 & 74 \\
\hline $0.81-0.90$ & 63 & 76 & 67 & 66 & 75 & 45 \\
\hline $0.91-1.00$ & 29 & 37 & 35 & 24 & 43 & 19 \\
\hline
\end{tabular}

Figure 2. Manufacturing competitiveness in different AUD/USD ranges [Ai Group, 2015]

As can be seen in Figure 2 a high Australian dollar is a major reason why the manufacturing sector has struggling. Over the past 10 years the Australian dollar has remained close to parity with its American counterpart. This has been due to high commodity prices correlating with a mining boom in Australia. Only recently has the AUD fell below 80 US cents and this has seen the PMI for the first time in 6 years rise over 50 [Ai Group, 2015]. Excluding a big fundamental change in the managerial and investment decisions in a manufacturing firm, a 


\section{Macrothink}

Journal of Public Administration and Governance

ISSN 2161-7104

2017, Vol. 7, No. 3

low Australian dollar will always be needed for most industries to remain competitive.

Advanced manufacturing has provided many countries with a renewed outlook on manufacturing. New advanced manufacturing technologies provide many first world countries including Australia the ability to reclaim some of the sector lost to offshoring. Customisation, low cost, reduced time, precision and improved quality are evident in these technologies particularly 3D printing. 3D printing takes advantage of all of these elements and has already proven to be successful in Australia [Warren, 2015].

The end of local car manufacturing in Australia will see thousands of manufacturing jobs lost. The government has tried to address this through implementing a 50 billion dollar submarine building contract with a French consortium. This may provide a new, much needed boost to the industry only if the submarines are built to a high standard. Any delays and waste of funds/resources would in fact worsen the public perception of Australian manufacturing.

A significant consequence that has been found with a declining manufacturing industry is the loss of local talent to overseas nations. Once this talent is lost it is very hard to regain. If the trends are not reversed the sector may never be in a position to recover; leaving Australia reliant on other countries to manufacture their goods [Ai Group, 2015].

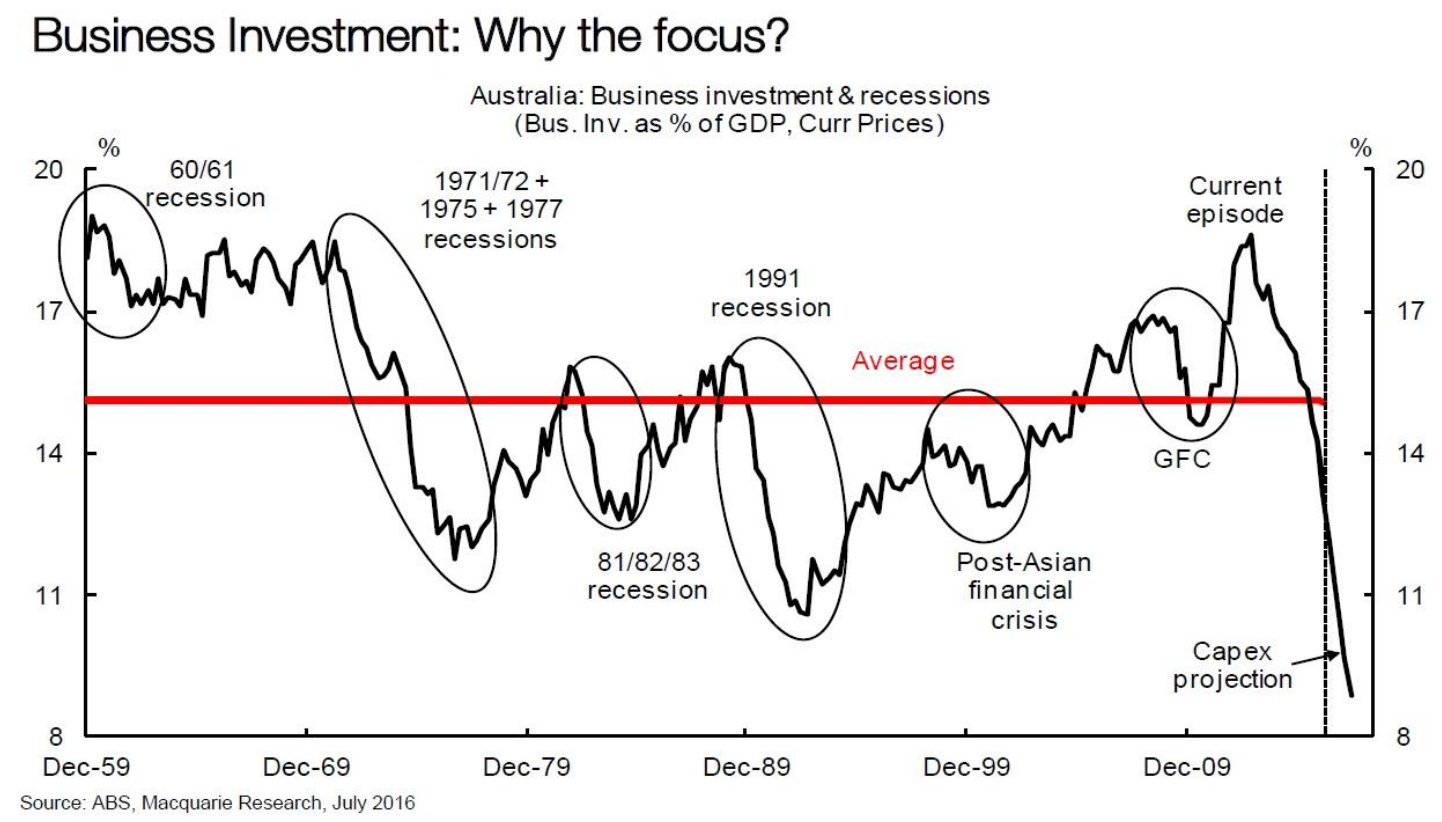

Figure 3. Australian business capital expenditure over the past 60 years [Colgan, 2016]

Figure 3 illustrates the capital expenditure spent by Australian businesses over the last 60 years [Colgan, 2016]. All large 'cliffs' have occurred during economic recessionary periods. The large spike that arises post GFC (Global Financial Crisis) was predominantly due to increased mining investment. Mining investment has since reduced and other economic drivers such as manufacturing have not increased investment. The major issue that this graph is able to demonstrate is that Australian businesses including manufacturers are not seeing 
investment as step forward in increasing revenue, productivity and competitiveness. New AMT investment generally has a high capital cost [Challis et al., 2005] and without the willingness to invest Australian manufacturers may lose the ability to reform in the new knowledge based economy.

\subsection{Results from Interviews}

All interviews were able to provide unique commentary on the current state of manufacturing in Australia. There were five interview participants from four different Australian businesses. For confidentiality the companies are referred to as Company A, B, C and D.

Company A is a 117 year old family run Australian business that specialise in the manufacture of mattresses. The company currently operate seven facilities across Australia and New Zealand and produce 1000 to 1500 mattresses per day. Most notably it has recently started exporting their mattresses to China. Over 50 high end Chinese stores sell these mattresses to the Chinese upper class. The highest end model, is handmade and takes approximately 240 hours to make, retails for $\$ 75,000$ US Dollars. All mattresses are made to order using the just in time manufacturing approach. Just in time has been publicised as an effective way of maximising the efficiency of advanced manufacturing technologies (Challis, Samson, Lawson 2004). It takes in the region of 3 to 5 days to produce a mattress from raw materials.

Company B is an Australian owned composite technology and manufacturing company. It currently produces chemical tankers used in the trucking industry. These tanks are both designed and manufactured in Australia. The tanks are made from carbon fibre and can carry a large variety of liquids ranging from industrial chemicals to milk. These tanks are loaded onto commercial trailers and then transported all over Australia. Most standard tankers are made of steel which is considerably heavier than carbon fibre. The tanks carbon fibre construction results in the reduction of the overall tankers weight, an increase in safety and an increased number of liquids that can be transported.

Company C was formed in 1856 in Adelaide, South Australia. Initially the company produced equipment for the equine industry such as saddles. At the turn of the $20^{\text {th }}$ century the company moved into spare parts manufacturing and vehicle repairing. In 1931 it became a subsidiary with a large auto manufacturer in the USA. This enabled the company to expand their facilities and focus on producing the first Australian made civilian car. Since, the company has been a staple of Australian car manufacturing and of the manufacturing sector in general.. Today it employs approximately 3,000 people in various roles and has lost significant ground in the new car sales market in Australia.

Company D has been involved in the Australian manufacturing sector for over 50 years. The organisation assists companies looking to purchase or implement new advanced manufacturing technologies and practices in order to provide a competitive edge on their products. It is a non-for-profit entity. The organisation uses focus groups rather than concentrating on individual companies to help find avenues to improve a company's manufacturing performance and efficiency. 


\section{Macrothink}

\section{Discussion and Recommendations}

Manufacturing in Australia has been plagued by protectionism, a strong domestic currency, high labour prices and a rapidly developing technological environment. It is important to distinguish why the industry has been either too slow to adapt to these changes or has refused to innovate. The sector at present is poorly meeting the new demands of consumers both domestically and internationally. Without major reform the sector will continue to decline to a point were 'Made in Australia' will be a rarity.

\subsection{Is AMT the Way forward for Manufacturing in Australia?}

AMT presently is the best investment Australian manufacturing has to transform the ailing sector into becoming a globally competitive exporter. Additive manufacturing, renewable energy technology and pharmaceutical manufacturing have experienced an immense increase in demand over the past decade. Additive manufacturing is able to substantially decrease production time while reducing costs. The CSIRO (Commonwealth Science and Industrial Research Organisation) has invested \$6 million dollars into five new state of the art 3D printing machines at a new facility named 'Lab 22' [2016]. The primary goal of this facility is to support industry partners who cannot afford the high capital costs incorporated with these large printers. These companies are able to use these printers based on a user pay-per-use model. This approach is precisely what the government should be doing to assist the sector in using this new technology. The CSIRO additionally offers 45 staff that are able to assist industry partners on how to most efficiently use these 3D printers.

An Australian vehicle component company Albins, was able to effectively use the CSIRO 3D printers in order to manufacture an urgent vehicle component for their client Thales. The 3D printer was able to produce a sand mould used for metal casting. A traditional mould may take upwards of a one month to be produced whereas the printed version took only one week. The cost to print was considerable cheaper compared to traditional means. Figure 4 depicts the sand mould that was produced by the printer in question.

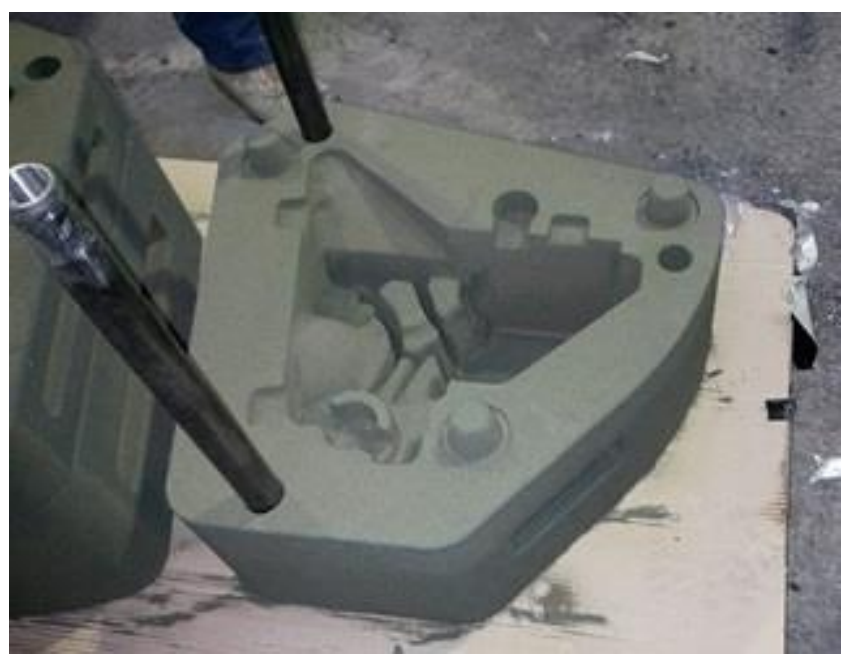

Figure 4. Figure of sand mould (CSIRO 2016)

Renewable energy investment has increased substantially since the 2007 ratification of the 
Kyoto Protocol. Australian universities, particularly UNSW (University of New South Wales) has been at the forefront of photovoltaic research. It is time to translate this research prowess into a manufacturing reality. This has not been done effectively by the industry as there is only one Australian company that manufactures solar panels [Baldwin, 2014].

A decade ago it was unthinkable that Chinese nationals would fund their Australian holiday by hoarding baby-formula and multivitamins back to China. In 2016 this is not only a reality but has quadrupled the Australian pharmaceutical company Blackmores profits in the space of five years [Korporaal, 2015]. China has an enormous market that are demanding high quality health products currently not available in China. Blackmores has hired an additional 100 employees and invested over half a million dollars into new technology for their production plant. Australian manufacturers need to better understand how they can engage with the Chinese market through the use of AMT to improve their manufacturing operations.

\subsection{Tariffs and Protectionism}

Protectionism has been identified as a key reason for the lack of competitiveness in Australian made products in the $20^{\text {th }}$ century. It is clear that most tariffs should be removed or reduced in order to force businesses to adapt to an ever-changing global market. Michael Emmery makes it clear in his research paper for the Australian government that trade liberalisation is a necessity for the nation to grow [Emmery, 1999]. Unfortunately certain politicians in the new 2016 senate have pushed for an increase in tariffs to help local manufacturing industries [Anderson, 2016]. Nick Xenophon, a South Australian senator has alerted his dislikes of free trade agreements, the removal of the ATS and weaker anti-dumping laws. This goes against most of the research evidence presented in the literature review. Dumping should always be a concern but for the Australian steel industry it is also clear that many investment decisions had not prioritised decreasing manufacturing costs during times of high steel prices. Australia needs to be concerned with not falling into the same trap of the 1960s only to keep people in jobs.

A good example of what needs to happen is government facilitating investment and innovation similar to the Victorian government buying Holden's Fishermans Bend site [2016]. The state government has decided to buy the site in order to turn it into an advanced industrial hub. This hub will assist new manufacturing businesses to collaborate and design in an environment which fosters innovation.

\subsection{Corporate Taxes}

Corporate taxes was a characterising issue in the 2016 federal election. The general public seemed divided on whether a reduction in the corporate tax rate of $5 \%$ was either a handout to big business or a simple way to boost investment and job creation. 


\section{Public Perception}

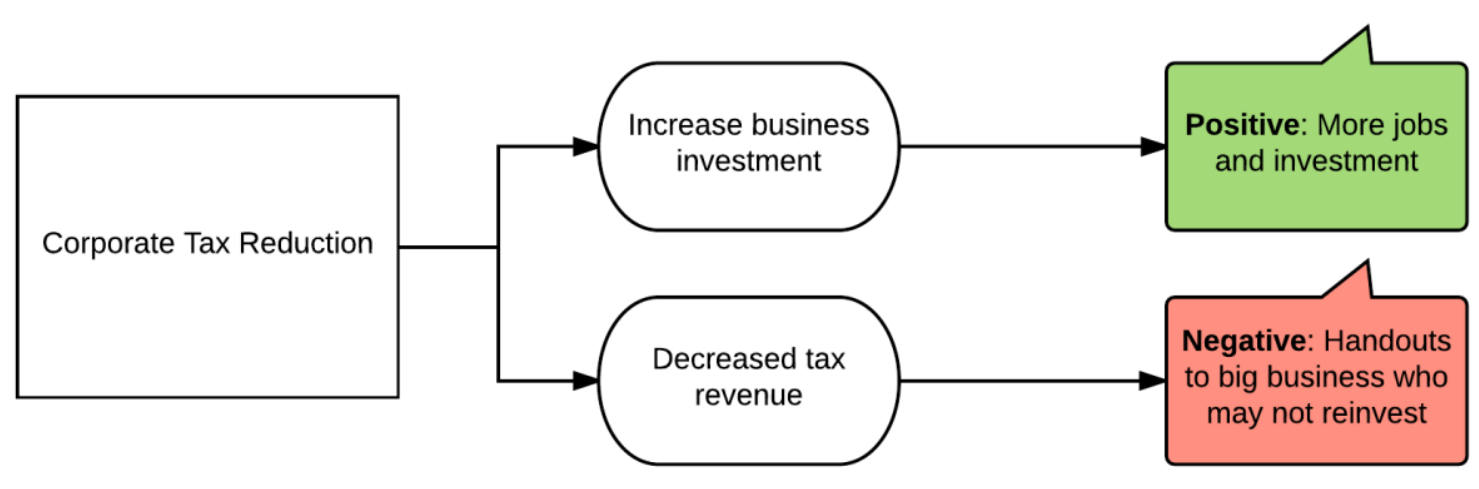

Figure 5. Corporate tax reduction flow chart

Figure 5 is able to illustrate the two common ideologies to this policy. As CSL have said a reduction from $30 \%$ to a $10 \%$ corporate tax rate on companies who manufacture products in Australia would be effective in encouraging investment. For small and medium size enterprises this is true however large businesses need to make the case to the public that these tax cuts will be put back into the sector. Corporate tax cuts do however remain a very effective mechanism to gradually increase business investment.

\subsection{Can Industry Work Better with Researchers?}

As the WEF Global Competitiveness Report highlighted Australia does noticeable worse than other OECD nations when it comes to university and industry interaction [Ai Group, 2015]. This must be a clear objective for industry as most of the technological advances useful to manufacturing is derived from universities. Strong links evident in countries such as Germany and the US allow businesses in these locations to be innovative. In the participant interviews A.H Beard had stated that they are working in collaboration with Monash University on spring systems and support systems technology. This is a significant step in the right direction as both universities and the industry benefit from collaboration.

\subsection{Public Perception of Manufacturing and Current Political Climate}

The current political climate in Australia has been increasingly hostile to foreign investment and trade. Recent decisions by the federal government including blocking the sale of Kidman \& Co's pastoral land and Ausgrid to Chinese investors has called into question Australia's sovereign risk [Barbour, et al., 2016]. Nation security concerns have been quoted as the reason for the block of sale. Unfortunately the election of commonwealth senators who perpetrate an anti-immigration mantra such as Pauline Hanson hurt the government's justifications on foreign investment and policy. Assisting the Australian manufacturing sector to export their products especially to Asia will mean that Australia must also open its doors to foreign capital. The government does not need to accept all foreign investment but it should not facilitate the perception that it is unwilling to work with nations who want to invest 
within Australia.

Public perception of Australian made goods has slumped over the recent decades. This is fortunately not the circumstance in many Asian nations. Australian made products are seen as safe, high quality and well made in these countries [Korporaal, 2015]). Peter Rufus from Holden has furthermore mentioned that there exist a general perception that Japanese made or German made cars are better than an Australian made car. These ideas damage the sector especially when these claims cannot be substantiated.

The government should investigate the means of increasing a positive domestic perception of Australian made products while not hindering foreign investment and trade. A fine balance is needed in order to correctly aid both sides.

\subsection{What Other Countries Are Doing}

Made in China 2025 aims to revolutionise China's manufacturing sector into an incubator of innovation and technological advancement [Liu, 2016]. Germany has learned to integrate different managerial systems to foster adoption of AMT [Hofmann, 2005]. Many western nations have identified that in order to remain competitive in the current global market manufacturers must be able to adapt and invest in new technology. A common method for driving investment is corporate tax reduction. In 1983 the U.K had a corporate tax rate of $52 \%$. The current rate is $20 \%$ with legislation pending to reduce the rate to $17 \%$ by 2020 [Midgley, 2016]. The reduction to $20 \%$ has seen business investment sharply increase. Ireland's economy grew by $26.3 \%$ in 2015 with a major corporate tax reduction to $12.5 \%$ [Chapman, 2016]. Corporations shipped their headquarters to Ireland in order to take advantage of this low tax rate. Unfortunately this has not resulted in an increase in jobs. The only benefit has been in Ireland's tax revenue. Corporate tax reduction has the ability to bring both domestic and foreign investment but must be done appropriately. In the 2000s Canada underwent corporate tax reduction which did not result in increased business investment. As a consequence the current government has floated ideas on raising corporate tax to compensate for the reduction in government revenue [Standford, 2016].

\subsection{Discussion on Interview Trends}

There are several trends that have emerged from the interviews which provide a different perspective to what is currently communicated in the literature. All interview participants acknowledged that either the manufacturing sector in this country will continue to decline or merely plateau. When asked if advanced manufacturing is key to the sectors growth most participants agreed with the premise. Company B specifically mentions the potential of embedded IP products to provide this growth while Company D identified high value added products may provide this growth. For Company A the efficiency of which they use their manufacturing processes deciphers the potential a technology has for growth within their business.

Company $\mathrm{C}$ and Company D both commented that advanced manufacturing technologies such as robotics and 3D printing are not new technologies. These technologies have existed in the industry for decades and are not the solution to transforming the sector. These 
technologies should not be shunned away but seem to get much unworthy attention in the press as 'game-changers' to the sector. Both additionally acknowledged that the public and many politicians appear to not understand the term 'advanced manufacturing' at all. Advanced manufacturing is a more holistic approach to manufacturing that accompanies more than new technologies that could be used in the manufacturing sector. It is about doing manufacturing better from an efficiency, managerial, global and economic point of view. Company B added to this discussion that "advanced manufacturing involves knowing how to make a product when your competitor does not know how".

The problems and issues plaguing the Australian manufacturing sector varied for all participants. All agreed that Australia's geographical location to the rest of the world was a hindrance to exportation. Australia's small population also exacerbated the geographical issue. Company A have seven facilities across Australia and New Zealand due to the extraordinary size of Australia. It is not practical for the company to have fewer facilities as the time lost to transportation can have a deep impact on their business.

All participants additionally mentioned that the Australian dollar has a significant impact on manufacturing in Australia. Manufacturers cannot control the currency exchange rate but Company A, B and C agree that a 70-80 cent AUD to USD range mentioned by the Ai Group is a very comfortable range for many manufacturing businesses. Generally a high Australian dollar has a negative impact on manufacturing in this country. The only positive is that raw materials may be purchased at a lower cost. This does however depend on whether each individual business does import raw materials.

Company A and Company B remark that Australian labour costs are a considerable factor when comparing the manufacturing sector to the rest of the work. Australia labour cost are higher than that of the US, China, South East Asia and many European nations. For some manufacturers this may act as a significant influence on whether they choose to manufacture in Australia or not. Company $\mathrm{C}$ and Company D have contrastingly different opinions on this issue. Company $\mathrm{C}$ mentions that how a former boss described Australian labour as "cheap" in the GM Corporation when the AUD to USD currency rate is low. Company D on the other hand explains that labour cost (3\%-10\%) should be insignificant in the overall cost of a product. He makes the claim that a well manufactured technological product should have approximately $3 \%$ labour cost. This means that labour cost should not been seen as the large burden that it is made out to be in Australia.

Company A and D mention how Australians come up with great innovative ideas and designs but they usually do not come to market in Australia. Either they are not given the support to bring these ideas to market or they are bought by international corporations who then apply these ideas and designs in a nation where they can make the most profit. This is a large downfall in the product development process.

Company A and Company D agree that middle management has great potential to drive growth in a manufacturing business. For Company A listening to middle management has resulted in significant changes in how they manufacturer their products and in turn has improved their efficiency. Changing their new Padstow facility to what was recommended by 


\section{Al Macrothink}

middle management was a direct example of this.

Company A elaborated on how they are now focusing on exporting their mattresses to a larger Asian market. $\mathrm{B}$ and $\mathrm{C}$ mention how this is not always possible depending on the product being sold. Company A's tanks are most beneficial in the European and US market where strict regulations exist on the maximum allowable mass per axle. In many Asian nations, similar standards like this don't exist or may not be enforced. This means that there is no incentive from that region to currently buy their product. With Company $\mathrm{C}$ many of the cars that were manufactured in Australia did not suit the Asian market. The type of product that is manufactured will heavily depend on whether it is desired in Asia.

\subsection{Recommendations for the Sector in Regards to Policy}

The National Innovation and Science Agenda set by the Turnbull government in 2015 is a step in the right direction in order to help rejuvenate the manufacturing sector. Unfortunately increased industry university collaboration, small tax breaks and entrepreneurship visa giveaways are not enough to create fundamental change. By analysing the results, changes that the government can adopt to help the sector include:

- Increasing government expenditure on AMT in the science and research priorities fund [Department of Industry, 2015]. An increase to a billion dollars will jumpstart local investment.

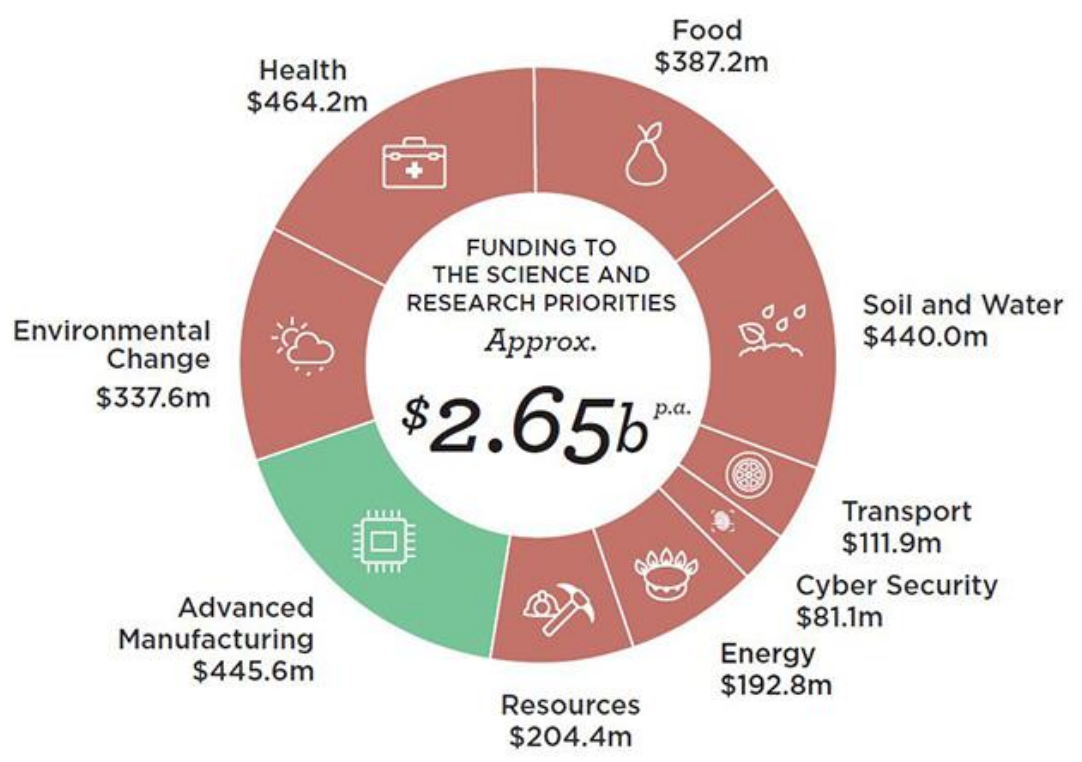

Figure 6. Australian government expenditure and research priorities (Department of Industry, Innovation and Science 2015)

- Reduction in the corporate tax rate specifically for companies manufacturing products in Australia

- No increase and no new tariffs or anti-dumping legislation. If anti-dumping legislation is needed a complete review of an industry must be conducted in order to make sure that 
dumping is the actual issue.

- Encouragement of the public to purchase locally produced goods. This may be effectively done through a standardisation of the "Australian Made" logo. Several logos exists but only the government can properly enforce the standardisation.

- Improving public infrastructure such as shipping ports, interstate highways and locomotive services. A significant obstacle is the size of Australia and its global isolation. Improving these amenities aids businesses wanting to expand their exports or increase their importation of raw materials.

- Having a strong focus on a specific type of manufacturing to help guide the sector. Identifying what Australian manufacturers are good at and then focusing policy on this will provide certainty for the sector and for manufacturing businesses.

- Providing an environment to foster innovation and start-ups through new technology parks and government funded incubators. Nurturing these start-ups will help to keep them operating in Australia if they ever evolve into large businesses.

\subsection{Recommendations for Manufacturing Companies and Firms}

The government is not only responsible for the decrease in manufacturing activity in Australia. A large burden falls on medium and large manufacturing firms and businesses who have not adapted to the changing world. Many changes can be made including:

- Allowing middle management to engage in purchasing AMT as stated in Hofmann and Orr's study

- Actively pursuing universities about new technologies that may be incorporated in their business or product

- Taking advantage of brand Australia especially in the Asia Pacific market

- Increasing investment in $R \& D$ and taking advantage of government incentives for innovation

- Becoming more globally orientated in order to diversify consumer base

- Increasing investment in renewable energy, biotechnology, pharmaceuticals and automation

- Providing more client and consumer customisation without an increased price

- Improving quality while decreasing production costs

If these changes were to be implemented by both government and business the Australian manufacturing sector may be able to reverse its current negative trajectory. It is important to note that this will take a considerable amount of time as sector-wide change is not easy.

It must be noted that potential sources of error may exist in this study. The literature review is predominantly based on academic literature and government publications. The study has 
attempted to balance these secondary sources with primary sources from individuals currently employed or involved in the Australian manufacturing sector. These opinions are inherently based on a participant's individual experiences and beliefs. This may lead to unintentional bias and could potentially skew the thesis. The best attempt has been made in order to minimise any bias from influencing the recommendations put forward in this thesis.

\section{Conclusion}

The thesis intended to examine and evaluate the current condition of manufacturing in Australia. This was achieved through researching the history of manufacturing in Australia starting from the 1960s and interviewing individuals and businesses involved in the sector. The literature illustrated how the sector has been in constant decline over the past 50 years. Tariff removal, a high Australian dollar and an increasingly globalised world were identified as some of the primary causes of this decline. The interviews conducted provided a unique perspective of the sector. Some businesses highlighted the geographical isolation of the nation, the low population, high labour costs and the high Australian dollar as some of the barriers to growth of the sector.

Both the literature and interview participants appear to agree that advanced manufacturing and placing a focus on high value products as an avenue for the sector's growth. The need for government intervention is not as large of a concern as mentioned in the literature. Contrastingly the literature suggested that university and industry collaboration was not at adequate levels. This was not the case with most interview participants having some form of research link with an Australian university.

The examination of primary sources obtained through interviews with secondary sources obtained from literature provides a new way of analysing the sector that is currently not available. Raw figures and data cannot provide the complete picture on the state of manufacturing in Australia. The findings made throughout this thesis may significantly aid businesses or the government when determining the best step forward for manufacturing. Recommendations including reducing corporate tax, improving public infrastructure, utilising new AMT and focusing on the Asia Pacific market will help the sector to grow albeit slowly.

This research is hampered by the scope of the topic it covers. It is impractical to interview every manufacturing business and see what personally may be done to aid in their growth. Innovation cannot be forced. It may be nurtured but the creation of good ideas will always take time and is something that businesses and governments cannot control. Finally the global economy will always have the biggest influence on any industry in Australia. Droughts, feminine, wars, natural disasters, commodity prices and perception may affect the trend in manufacturing for better or for worse. This however does not mean that governments and businesses should not attempt to reform.

\section{References}

Ai Group. (2015). Australian Dollar Fact Pack, accessed 5 April 2016, http://www.aigroup.com.au/portal/binary/com.epicentric.contentmanagement.servlet.Content DeliveryServlet/LIVE_CONTENT/Publications/Reports/2015/Australian\%2520Dollar\%2520 


\section{Macrothink}

Journal of Public Administration and Governance

ISSN 2161-7104

2017, Vol. 7, No. 3

Fact\%2520Pack.pdf

Anderson, F. (2016). Protection taunt riles Malcolm Turnbull's much needed Senate ally Nick Xenophon, Australian Financial Review, accessed 17 September 2016, $<$ http://www.afr.com/news/politics/protection-taunt-riles-malcolm-turnbulls-much-needed-se nate-ally-nick-xenophon-20160819-gqwcl2>

Baldwin, J. (2014). Australia's only solar panel manufacturer receive \$20 million financing from CEFC, The Lead South Australia, accessed 10 September 2016, http://www.theleadsouthaustralia.com.au/industries/manufacturing/australias-only-solar-panel -manufacturer-receives-20-million-financing-from-cefc/

Barbour, L, Vidot, A, \& Gunders, J. (2016). Scott Morrison knocks back sale of S. Kidman \& Co due to 'national interest', ABC News, 30 April, accessed 15 October 2016, http://www.abc.net.au/news/2016-04-29/sale-of-s.-kidman-\&-co-'contrary-to-national-interest ':-morrison/7370926

Challis, D., Samson, D., \& Lawson, B. (2005). Impact of technological, organizational and human resource investments on employee and manufacturing performance: Australian and New Zealand evidence. International journal of production research, 43(1), 81-107. https://doi.org/10.1080/00207540412331281935

Chapman, B. (2016). Ireland's economy grows $26.3 \%$ in 2015 as corporations flock to low tax rate, The Independent, 13 July, accessed 15 October 2016, < http://www.independent.co.uk/news/business/news/ireland-s-economy-grows-263-in-2015-as -corporations-flock-to-low-tax-rate-a7133321.html>

Colgan, P. (2016). Australia's unprecedented collapse in business investment, in one chart, Business Insider, 22 August, accessed 1 September 2016, http://www.businessinsider.com.au/australias-unprecedented-collapse-in-business-investment -in-one-chart-2016-8

Davidson, F. (1969). The Significance of Manufacturing in Australia. Australian Economic Review, 2(3), 37, Business Source Premier, EBSCOhost, accessed 10 October 2015. https://doi.org/10.1111/j.1467-8462.1969.tb00078.x

Department of Industry, Innovation and Science. (2015). Advanced ManufacturingCapability, Australian Government, accessed 17 September 2016, $<$ http://www.science.gov.au/scienceGov/ScienceAndResearchPriorities/Pages/Advanced-man ufacturing.aspx>

Emmery, M. (1999). Australian manufacturing: a brief history of industry policy and trade liberalisation, Department of the Parliamentary Library.

Hasan, M., \& Chung, W. (2011). 'Manufacturing in Australia - a Historical Perspective', in Proceedings 2011 IEEE International Summer Conference of Asia Pacific Business Innovation and Technology Management, APBITM, China, pp. 158 - 162, presented at 2011 International (Summer) Conference of APBITM, China, Dalian, China, 1 July 2011. 
https://doi.org/10.1109/apbitm.2011.5996313

Hofmann, C., \& Orr, S. (2005). Advanced manufacturing technology adoption-the German experience. Technovation, 25(7), 711-724. https://doi.org/10.1016/j.technovation.2003.12.002

Inside Lab 22. (2016). Create Magazine Engineers Australia, 7 August, p.52

Korporaal, G. (2015). Blackmores gets a dose of good medicine as Chinese sales soar, The Australian, $\quad$ accessed $10 \quad$ September 2016, http://www.theaustralian.com.au/business/companies/blackmores-gets-a-dose-of-good-medici ne-as-chinese-sales-soar/news-story/0d84179b399e79aaedc9b670b604eb9a

Liu, S. (2016). Innovation Design: Made in China 2025, Design Management Review, 27, 52-58. https://doi.org/10.1111/drev.10349

Midgley, G. (2016). Could a corporation tax rate of $15 \%$ work for the UK? The Conversation, $8 \quad$ July, $\quad 15 \quad$ accessed $\quad 15$ October https://theconversation.com/could-a-corporation-tax-rate-of-15-work-for-the-uk-62011>

Perlich, H. (2012). Economic notes: Australia's two-speed economy. Journal of Australian Political Economy, The, No. 72, Summer 2013/2014: 106-126, accessed 10 October 2015, <http://search.informit.com.au.wwwproxy0.library.unsw.edu.au/documentSummary; $\mathrm{dn}=8465$ 72971694273;res=IELAPA > ISSN: 0156-5826.

Prime Minister's Manufacturing Taskforce. (2012). Smart Manufacturing for a smarter Australia, AGPS, Canberra.

Productivity Commission. (2003). Trends in Australian Manufacturing, AGPS, Canberra.

Productivity Commission. (2014). PC Productivity Update 2015, AGPS, Canberra.

Standford, J. (2016). A Warning From Canada: How Cutting Corporate Tax Did More Harm Than Good, New Matilda, 3 March, accessed 15 October 2016, < https://newmatilda.com/2016/03/03/a-warning-from-canada-how-cutting-corporate-tax-did-m ore-harm-than-good/>

Vic government buys Holden site, announces high-value industrial hub plans. Manufacturers' Monthly, 14 September 2016, accessed 17 September 2016, http://www.manmonthly.com.au/news/vic-government-buys-holden-site-announces-high-<va lue-industrial-hub-plans/>

Warren, A. (2015). How our 3D print tech lead to jet-set success. CSIRO Australia, accessed 6 May 2016, https://blog.csiro.au/how-our-3d-print-tech-led-to-jet-set-success/

\section{Copyright Disclaimer}

Copyright for this article is retained by the author(s), with first publication rights granted to the journal.

This is an open-access article distributed under the terms and conditions of the Creative Commons Attribution license (http://creativecommons.org/licenses/by/4.0/). 